\title{
PERAN DATA DALAM MANAJEMEN PERPUSTAKAAN DI INDONESIA
}

\author{
Anindya Gita $\mathbf{P}^{*}$
}

Pengutipan: Gita P, A. (2017). Peran Data dalam Manajemen Perpustakaan di Indonesia. Khizanah Al-Hikmah : Jurnal Ilmu Perpustakaan, Informasi, dan Kearsipan. 5(2), 160-163.

DOI: http://doi.org/10.24252/kah.v5i2a3

\author{
*Mahasiswa Universitas Islam Negeri Sunan Kalijaga Yogyakarta \\ anindyagita@gmail.com
}

\begin{abstract}
ABSTRAK
Perpustakaan senantiasa mendorong penggunanya untuk mencari dan menggunakan informasi yang terpercaya dan telah teruji. Oleh karena itu sudah seharusnya perpustakaan juga melakukan upaya pencarian informasi mengenai "dirinya" melalui riset untuk mendapatkan data. Upaya pencarian informasi ini di Indonesia umumnya masih sebatas data koleksi, data peminjaman, dan kunjungan pengguna. Ada banyak opini dan kekhawatiran yang bervariasi yang disampaikan oleh pustakawan dan staf dalam pengembangan perpustakaan. Data dapat menjadi pelengkap pemikiran disini, juga sebagai penengah berbagai pemikiran. Berdasarkan pemaparan tersebut maka peneliti tertarik untuk membahas bagaimana posisi data dalam manajemen perpustakaan. Keberadaan data sangat penting sebagai dasar dalam mengambil keputusan di perpustakaan. Begitu juga dalam manajemen perpustakaan, seorang kepala perpustakaan harus melakukan riset terlebih dahulu untuk memperoleh data yang digunakan untuk mengambil kebijakan.

Kata kunci: Data, Manajemen Data, Manajemen Perpustakaan

\section{ABSTRACT}

The library constantly encourages its users to search and use reliable and tested information. Therefore the library should also make efforts to search information about "itself" through research to obtain data. This information search effort in Indonesia is generally still limited to data collection, lending data, and user visits. There are many varied opinions and concerns delivered by librarians and staff in library development. Data can be a complement to thinking here, as well as mediating thoughts. Based on the exposure, the researcher is interested to discuss how the data position in library management. The existence of data is very important as the basis for making decisions in the library. Likewise in library management, a library head should research first in order to obtain the data used to take policy.

Keywords: Data, Data Management, Library Management
\end{abstract}

\section{PENDAHULUAN}

Paradigma pelayanan saat ini mengalami perubahan dari new public management ke new public service. Perubahan ini memiliki arti bahwa pelayanan adalah pemenuhan kebutuhan pengguna sehingga pengguna merasa puas. Oleh karena itulah kualitas pelayanan menjadi penting (Heffy, 2011). Perpustakaan sebagai institusi yang memberikan pelayanan perlu memikirkan strategi pengembangan perpustakaan agar dapat memberikan pelayanan yang berkualitas kepada pengguna. Kualitas pelayanan perpustakaan dapat dilihat dari tersedianya informasi yang dibutuhkan pengguna.

Selain memiliki fungsi sebagai penyedia informasi, perpustakaan senantiasa 
mendorong penggunanya untuk mencari dan menggunakan informasi yang terpercaya dan telah teruji. Oleh karena itu sudah seharusnya perpustakaan juga melakukan upaya pencarian informasi mengenai "dirinya" melalui riset untuk mendapatkan informasi atau data yang berkualitas. Upaya pencarian informasi ini di Indonesia umumnya masih sebatas data koleksi, data peminjaman, dan kunjungan pengguna. Data ini juga umumnya hanya digunakan sebagai syarat dalam akreditasi perpustakaan tanpa memahami fungsi data bagi manajemen perpustakaan.

Perpustakaan UIN Sunan Kalijaga dan Perpustakaan UGM sebagai perpustakaan perguruan tinggi memiliki banyak data riset mengenai perpustakaannya karena institusi induknya yaitu UIN Sunan Kalijaga dan UGM memiliki jurusan perpustakaan. Mahasiswa melakukan berbagai macam riset di perpustakaan ini setiap tahunnya. Namun hal seperti ini belum tentu terjadi di perpustakaan lainnya di Indonesia. Ada banyak opini dan kekhawatiran yang bervariasi yang disampaikan oleh pustakawan dan staf dalam pengembangan perpustakaan. Data dapat menjadi pelengkap pemikiran disini, juga sebagai penengah berbagai pemikiran (Massis, 2016). Berdasarkan pemaparan tersebut maka peneliti tertarik untuk membahas bagaimana posisi data dalam manajemen perpustakaan. Setelah membaca makalah ini penulis berharap pembaca dapat memahami pentingnya data dalam manajemen perpustakaan.

\section{PEMBAHASAN}

\section{a. Data Dan Library Data}

Secara teknis, Data adalah catatan atas sekumpulan fakta. Data merupakan bentuk jamak dari datum berasal dari bahasa latin yang berarti "sesuatu yang diberikan". Dalam penggunaan sehari-hari data berarti suatu pernyataan yang di terima apa adanya. Pernyataan ini adalah hasil pengukuran atau pengamatan suatu variabel yang bentuknya dapat berupa angka, kata, maupun citra. Data adalah sesuatu yang belum mempunyai arti bagi penerimanya dan masih membutuhkan adanya suatu pengolahan. Dalam keilmuan, fakta dikumpulkan menjadi sebuah data. Data kemudian diolah sehingga bisa diutarakan secara jelas dan tepat sehingga dapat di mengerti oleh orang lain (Vardiansyah, 2008).

Berdasarkan pengertian tersebut maka Library Data dapat diartikan sebagai data atau fakta yang dapat dikumpulkan perpustakaan. Ruang Lingkup Library data adalah sebagai berikut (Priyanto, 2016):

1) Data Sumber daya Perpustakaan (Library resource data) : library resource usage dan library resource effectiveness

2) Data Pemanfaatan Perpustakaan (Library usage data) : library space data, library interaction data, library visit data, dan online visit data

3) Data Pengguna Perpustakaan (Library user data): data demografi

4) Data Staff Perpustakaan (Library staff data): raw library staff data, librarians and their activities

Jika berbicara mengenai data maka mayoritas orang masih berpikir bahwa data identik dengan sesuatu yang rumit, baik dalam mendapatkannya maupun dalam pengelolaannya. Padahal kenyataanya justru sebaiknya dengan data kita justru dapat menyederhanakan pekerjaan, kita dapat mengelola suatu pekerjaan dengan tepat dan efektif. Data adalah modal utama untuk merencanakan dan memperbesar kemungkinan berhasil dalam sebuah - pekerjaan baik dalam lingkungan swasta maupun dalam instansi pemertintahan.

Data bisa kita analogikan sebagai "tongkat pemandu" untuk menentukan arah, prediksi , mengkalkulasi sehingga tercipta keputusan maupun kebijakan dalam sebuah manajemen. Namun sayangnya tidak semua orang yang memahami ini benar-benar mempraktekan penggunakaan data dalam setiap kebijakannya karena kurangnya kesadaran maupun demi keuntungan pribadi.

Di era informasi seperti saat ini, data sangat penting bagi perkembangan dan kemajuan suatu organisasi termasuk dalam 
manajemen organisasi perpustakaan. Keberadaan perpustakaan modern yang di tuntut untuk lebih komunikatif dan fasilitatif bagi pengunjung tentunya akan sangat membutuhkan data-data baik mengenai organisasi internal maupun pelayanan eksternal.

\section{b. Manajemen Perpustakaan}

Bryson dalam Qalyubi mengatakan bahwa manajemen perpustakaan merupakan upaya pencapaian tujuan dengan adanya pemanfaatan sumber daya manusia, informasi, sistem, dan sumber dana dengan tetap memperhatikan fungsi manajemen, peran, dan keahlian (Qalyubi, 2007). Ilmu manajemen merupakan ilmu dari disiplin ilmu lain yang diadopsi di perpustakaan. Penerapan manajemen di perpustakaan bermanfaat dalam mengelola organisasi dan pelayanan perpustakaan. Manajemen di Perpustakaan melingkupi manajemen koleksi, manajemen kepemimpinan, manajemen mutu, manajemen pelayanan, $\mathrm{dsb}$.

\begin{tabular}{cc|c} 
Dalam & menjalankan & manajemen \\
perpustakaan & pengambilan & keputusan
\end{tabular} mengenai kebijakan akan sering dilakukan. Baker dalam Janos Fulop mengatakan bahwa pengambilan keputusan seharusnya dimulai dari adanya masalah kemudian dilanjutkan dengan beberapa langkah pengambilan keputusan. Langkah pengambilan keputusan ini yaitu dengan memahami permasalahan, menentukan kebutuhan, menetapkan tujuan, mengidentifikasi alternatif masalah, mendefinisikan kriteria, memilih alat pengambilan keputusan, mengevaluasi, validasi solusi (fulop, 2005).

\section{c. Posisi Data Dalam Manajemen Perpustakaan}

Dalam rangka memberikan pelayanan yang berkualitas kepada pengguna perpustakaan menjalan manajemen perpustakaan baik. Sebagaimana yang telah disebutkan sebelumnya dalam menjalankan manajemen perpustakaan akan ditemui permasalahan yang membutuhkan penyelesaian masalah. Penyelesaian masalah ini harus diputuskan. Memahami masalah dan bagaimana penyelesaian maka pengambil keputusan di perpustakaan tentu membutuhkan data. Tanpa data maka perpustakaan hanya akan menjalankan manajemennya sesuka hati atau berdasarkan intuisi yang mungkin saja bisa tidak tepat sasaran.

Data dapat membantu perpustakaan memantau perkembangan perpustakaannya baik dari segi pemanfaatan. Selain itu adanya data bisa menjadi alat bagi perpustakaan untuk melakukan komunikasi dengan institusi induknya terkait pengambilan kebijakan.

Ada banyak data yang bisa digali dari perpustakaan seperti data kepuasan pengguna. Data-data mengenai kepuasan pelayanan kepada pengunjung memiliki banyak manfaat diantaranya sebagai berikut (Dinas Kelautan dan Perikanan, 2015):

1) Sebagai bahan atau alat dalam pengambilan keputusan

2) Menentukan jenis kegiatan atau program yang akan dilaksanakan

3) Alternatif/metode untuk melaksanakan kegiatan

4) Seberapa besar lingkup kegiatan

5) Penentu SDM pelaksanaan kegiatan

6) Estimasi waktu yang di butuhkan untuk pelaksanaan

7) Estimasi biaya yang di keluarkan untuk kegiatan

8) Acuan dalam evaluasi program kerja manajemen berikutnya.

Perpustakaan juga bisa menggali data mengenai kenyamanan pengguna terhadap kursi dan meja perpustakaan, bagaimana pemanfaatannya. Data ini bisa berbicara mengenai apakah kursi dan meja yang ada sudah dirasa nyaman oleh pengguna. Data ini bermanfaat dalam perencanaan desain tata ruang perpustakaan ke depannya.

Data penggunaan koleksi juga bermanfaat dalam manajemen koleksi perpustakaan. Pustakawan dapat mengetahui buku apa saja yang tidak pernah dimanfaatkan oleh 
pengguna, dan buku apa saja yang perlu di koleksi perpustakaan. Selain melakukan riset tersebut di perpustakaan, juga bisa dilakukan riset terkait motivasi staf perpustakaan, efektifitas sistem manajemen informasi, karakteristik pengunjung perpustakaan, pemanfaatan ruang di perpustakaan, dsb. Dari sini dapat kita lihat betapa pentingnya data dalam kinerja, kelancaran, dan kemajuan perpustakaan. Pihak manajemen perpustakan membutuhkan penyusunan data yang baik agar dapat membantu dalam evaluasi program kerja manajemen perpustakaan kedepannya.

\section{PENUTUP}

Keberadaan data sangat penting sebagai dasar dalam mengambil keputusan di perpustakaan. Begitu juga dalam manajemen perpustakaan, seorang kepala perpustakaan harus melakukan riset terlebih dahulu untuk memperoleh data yang digunakan untuk mengambil kebijakan.

\section{DAFTAR PUSTAKA}

Heffy, M. (2009). Reformasi Manajemen Pelayanan Publik Menuju Good Governance. Jurnal Borneo Administrasi, 5(2). Diakses dari http:// download.portalgaruda.org/arti cle.php?article $=250595 \&$ val $=6702 \&$ title $=$ reformasi $\% 20$ manajemen $\% 20$ pelayanan $\% 20$ publik\%20menuju \%20good \%20gov ernance.

Massis, B. (2016). Data Driven Decision Making In the Library. New Library World, 117(1/2), 131-134. DOI: 10.1108/NLW-10-2015-0081.

Vardiansyah, D. (2008). Filsafat Ilmu Komunikasi: Suatu Pengantar. Jakarta: Indeks.

Priyanto, I. F. (2016), Data Management, UINsesi 7. Disampaikan pada mata kuliah desain sistem informasi di UIN Sunan Kalijaga Yogyakarta.

Qalyubi, S. (2007). Dasar-Dasar Ilmu Perpustakaan dan Informasi. Yogyakarta: Jurusan Ilmu Perpustakaan Fakultas Adab UIN Sunan Kalijaga.
Fulop, J. (2016, 5 Juni). Introduction to Decision Making Methods. Diakses dari http:/ / academic.evergreen.edu/project $\mathrm{s} /$ bdei/documents/decisionmakingmet hods.pdf.

Dinas Kelautan dan Perikanan.(2016, 14 Juni), Arti Penting Data Prespektif Perencanaan. Diakses dari http://www.dislautkan.jogjaprov.go.id. 